\title{
PLANIRANJE POSLOVANJA \\ KAO FUNKCIJA RUKOVOĐENJA KNJIŽNICOM \\ S OSVRTOM NA PLANIRANJE UPRAVLJANJA KRIZOM
}

\author{
BUSINESS PLANNING AS A FUNCTION \\ OF LIBRARY MANAGEMENT WITH REFERENCE \\ TO CRISIS MANAGEMENT PLANNING
}

\begin{abstract}
Antal Balog
Veleučilište s pravom javnosti „Baltazar“ Zaprešić

antal.balog@bak.hr
\end{abstract}

UDK / UDC 005.7:021:025

Izvorni znanstveni rad / Original scientific paper

Primljeno / Received: 11. 12. 2020.

Prihvaćeno / Accepted: 2. 2. 2021.

\section{Sažetak}

Cilj ovog rada jest objasniti osnovne pojmove planiranja poslovanja kao funkcije rukovođenja, zatim planiranja operativnih i regulacijskih funkcija u knjižnici te povezanost misije i vizije s organizacijskim ciljevima i strategijama rada. Nadalje, cilj mu je pridonijeti boljem razumijevanju strateškog plana razvoja knjižnice, njegove uobičajene strukture, potom razradi strateških ciljeva na posebne (ili specifične) ciljeve i operativne zadaće te ključnih pokazatelja uspješnosti njegove provedbe. Završni dio teksta govori o operativnom ili godišnjem planiranju rada knjižnice uz kratki osvrt o planiranju upravljanja krizom, imajući u vidu aktualne krizne okolnosti, primjerice pandemiju, zemljotrese, poplave i tome slično.

Pristup/metodologija/oblikovanje. Rasprava započinje teorijskim uvodom u temu planiranja s daljnjom razradom općih pojmova i sadržaja strateškog i operativnog planiranja. U nastavku rada koristi se desk research metoda te metoda analize postojećih postupaka strateškog planiranja u knjižnicama te njihovih strateških i operativnih (godišnjih) planova. Autor predlaže primjer strukture sadržaja strateškog plana razvoja knjižnice koji povezuje dobre prakse domaćih knjižnica s teorijom suvremenog menadžmenta.

Vjesnik bibliotekara Hrvatske 64, 1(2021), 53-80

ISSN 0507-1925 
Rezultati ovog rada pridonose boljem razumijevanju i učinkovitijem procesu oblikovanja i donošenja strateških i operativnih planova knjižnice te njihova praćenja korištenjem ključnih pokazatelja uspješnosti provedbe.

Ograničenja. Istraživanje je ograničeno na knjižnice u Republici Hrvatskoj.

Praktična primjena. Sadržaj ovoga članka može pomoći knjižničarima i srodnim profesijama u razumijevanju planiranja kao funkcije rukovođenja u pripremi i provođenju strateških i operativnih planova knjižnice.

Društveni značaj ovoga članka sadržan je u boljem razumijevanju i mogućoj uspješnijoj primjeni teorijskih spoznaja strateškog i operativnog planiranja u poslovanju knjižnica kao ustanova od posebnog društvenog interesa.

Originalnost i vrijednost ovog rada jest u povezivanju teorijskih razmatranja strateškog i operativnog planiranja poslovanja knjižnica s njihovom praktičnom primjenom u upravljanju i rukovođenju.

Ključne riječi: operativno planiranje, planiranje poslovanja u knjižnicama, rukovođenje u knjižnicama, strateško planiranje, upravljanje krizom.

\section{Abstract}

Goal. The goal of this paper is to explain the basic concepts of business planning as a management function, then the planning of operational and regulatory functions in the library and the connection of mission and vision with organizational goals and work strategies. Furthermore, it aims to contribute to a better understanding of the strategic development plan of the library, its usual structure, then the elaboration of strategic goals on particular (or specific) goals and operational tasks and key performance indicators of its implementation. The final part of the text discusses the operational or annual planning of the library activities with a brief overview of crisis management planning, having in mind the current crisis circumstances caused by pandemics, earthquakes, floods, etc.

Approach/methodology/design. The discussion begins with a theoretical introduction to the topic of planning with further elaboration of general concepts and content of strategic and operational planning. The second part of the paper presents the use of the desk method of observation and analysis of the existing strategic planning procedures in libraries and their strategic and operational (annual) plans. The proposed example of the content structure of the strategic library development plan connects the practices of domestic libraries with the theory of modern management.

Results. The results of this paper contribute to a better understanding and more efficient process of designing and adopting strategic and operational plans of the library and their monitoring using key performance indicators. 
Limitations. The research is limited to libraries in the Republic of Croatia.

Practical implications. The content of this article can help librarians and related professions in understanding planning as a management function in the preparation and implementation of strategic and operational library plans.

Social implications. Social implications of this article are contained in a better understanding and a possible more successful application of theoretical knowledge of strategic and operational planning in library operations.

The originality and value. Connecting theoretical considerations of strategic and operational planning of library operations with their practical application in management and leadership.

Keywords: crisis management, library business planning, library management, operational planning, strategic planning

\section{Uvod: planiranje kao prva funkcija rukovođenja}

Prema stajalištu suvremenih autora, primjerice Weihricha i Koontza, rukovođenje (ili menadžment) ima nekoliko integriranih funkcija od kojih je jedna funkcija planiranja. Ostale četiri čine: (1) organiziranje, (2) upravljanje ljudskim potencijalima ili kadroviranje, (3) vodstvo ili liderstvo te (4) funkcija kontrole. ${ }^{1}$ Navedene funkcije rukovođenja imaju obilježja poslovnih procesa koji se završavaju poslovnim odlukama. Otuda bi se odlučivanje, u jednom širem smislu, moglo smatrati posebnom funkcijom rukovođenja koja, osim odgovarajućeg procesa, sadrži i završni čin, odnosno izbor među postojećim mogućnostima. Prema tome, svaka od funkcija rukovođenja, bilo da je to planiranje, organiziranje, kadroviranje, vodstvo ili kontrola, završava odlučivanjem, prvo kao procesom, a potom kao činom. U tom smislu, odlučivanje se može opisati kao glavni posao svakog menadžera. ${ }^{2}$

U praksi se navedene funkcije rukovođenja ne odvijaju sukcesivno, jedna za drugom već su međusobno isprepletene i često se odvijaju simultano. Međutim, u odnosu na druge funkcije, planiranje ima izvjesni primat, s obzirom na to da je svaku menadžersku funkciju potrebno prethodno isplanirati i uskladiti s drugim funkcijama.

Sve se poslovne funkcije u nekoj organizaciji mogu podijeliti na dvije osnovne skupine, na operativne i na regulacijske. Operativne se funkcije odnose na izvršavanje djelatnosti koje se obavljaju u knjižnici kako one knjižnične tako i neknjižnične. Za razliku od njih, regulacijske funkcije obuhvaćaju upravljanje i rukovo-

\footnotetext{
1 Prema Weihrich, H.; H. Koontz. Menadžment. 11. izd. Mate: Zagreb, 1998. Str. 20-21.

2 Usp. Jurina, M. Organizacija i menadžment. Visoka škola za poslovanje i upravljanje s pravom javnosti Baltazar Adam Krčelić: Zaprešić, 2011. Str. 156.
} 
đenje izvršavanjem operativnih funkcija. ${ }^{3}$ Imajući u vidu takvu podjelu, planiranje poslovanja u knjižnici može imati dva osnovna područja:

(1) planiranje operativnih funkcija koje rezultira izradom i donošenjem planskih dokumenata, primjerice strateških, operativnih i drugih, najčešće planova koji se odnose na određene odnosno posebne aktivnosti;

(2) planiranje regulacijskih funkcija, koje rezultira izradom i donošenjem regulacijskih dokumenata kojima se regulira donošenje programiranih odluka u odnosu na procese poslovanja, organizacijske resurse te upravljanje okruženjima, primjerice politike, procedure, pravila, programi, projekti i proračuni (budžeti).

Osim planiranja operativnih i regulacijskih funkcija u organizaciji i onih koje objedinjuju poslovanje tijekom redovitih okolnosti, potrebno je izdvojiti posebno područje planiranja koje se odnosi na poslovanje tijekom izvanrednih okolnosti.

\subsection{Planiranje operativnih funkcija u knjižnici}

Planiranje je poslovanja knjižnice proaktivno oblikovanje budućeg funkcioniranja ustanove u kojem se unaprijed definiraju aktivnosti i njihovo odvijanje $u$ organizacijskim strukturama u zadanom društvenom, političkom, ekonomskom i kulturološkom kontekstu, odnosno okruženju. Prema tome, planiranje rada knjižnice jest poslovni proces, dok su izrađeni planovi dokumenti koji sadrže rezultate procesa planiranja i koje je utvrdilo nadležno tijelo rukovođenja, a usvojilo ih nadležno tijelo upravljanja.

Planiranje poslovanja knjižnice ima dvije međusobno povezane zadaće. Prva se odnosi na određivanje organizacijskih ciljeva koji se žele postići, a druga na izbor načina na koje će se utvrđeni ciljevi ostvarivati. ${ }^{4}$ Obje navedene zadaće usmjerene su prema predviđanju poslovanja knjižice u neposrednoj budućnosti koja se nastoji oblikovati proaktivnim organizacijskim ponašanjem. Ili, drugim riječima, planiranje kao poslovna funkcija nastoji upravljati neposrednom organizacijskom budućnošću.

U operativnom smislu planiranje rada knjižnice usmjereno je na tri poslovna područja koja zahtijevaju unutarnje i međusobno usklađivanje. Prvo područje usklađivanja odnosi se na funkcioniranje organizacijskih jedinica i radnih mjesta u zadanoj organizacijskoj strukturi knjižnice. Drugo se područje odnosi na raspo-

\footnotetext{
3 Vidjeti u: Balog, A. Upravljanje knjižnicom kao poslovna funkcija. // Vjesnik bibliotekara Hrvatske 61, 2(2018), str. 86. [citirano: 2020-10-30]. Dostupno na https://www.hkdrustvo.hr/vjesnik-bibliotekara-hrvatske/index.php/vbh/article/view/666/595.

${ }_{4}$ Dobro je podsjetiti kako se ukupno poslovanje knjižnice može podijeliti na dvije osnovne skupine: na knjižnične djelatnosti i na neknjižnične djelatnosti. Vidjeti u: Balog, A. Prema oblikovanju organizacijske strukture knjižnice. // Vjesnik bibliotekara Hrvatske 63, 1-2(2020), str. 87. [citirano: 2021-01-30]. Dostupno na https://www.hkdrustvo.hr/vjesnik-bibliotekara-hrvatske/ index.php/vbh/article/view/789/683.
} 
ložive organizacijske resurse (materijalne, nematerijalne, kadrovske, vremenske, prostorne i financijske), a treće na usklađivanje koje se odnosi na postojeća okruženja knjižnice, odnosno na unutarnje i vanjsko okruženje. Prema tome, da bi se dugoročno uspješno usklađivalo funkcioniranja navedenih poslovnih područja, potrebno je učinkovito planiranje poslovanja knjižnice.

U planiranju poslovanja knjižnice osnovno je polazište izjava o misiji, odnosno izjava o njezinom poslanju, koja u sažetom obliku navodi razlog postojanja knjižnice. ${ }^{5}$ Vizija knjižnice, koja se naslanja na izjavu o misiji, u kratkoj izjavi opisuje organizacijsko funkcioniranje u određenoj budućnosti ili kako subjekti planiranja vide poslovanje knjižnice, primjerice, nakon pet godina.

Na temelju izjava o misiji i viziji, oblikuju se organizacijski ciljevi, koji predstavljaju operativnu konkretizaciju svrhe postojanja knjižnice i njezinog poslovanja u budućnosti. Drugim riječima, ciljevi su željena poslovna i organizacijska stanja u zadanoj bližoj ili daljnjoj budućnosti. S obzirom na vremensku dimenziju, ciljeve možemo razvrstati u tri skupine: (1) kratkoročne ciljeve, koje je potrebno ostvariti u roku od godine dana, (2) srednjoročne ciljeve, koji se odnose na razdoblje do pet godina i (3) dugoročne ciljeve, koji se trebaju ostvariti u razdoblju od pet do deset ili više godina. S obzirom na hijerarhijsku razinu, poslovni se ciljevi mogu razvrstati na: (1) strateške ciljeve, koji sadrže glavna nastojanja koja knjižnica, kao cijela organizacija, želi postići u zadanom, najčešće petogodišnjem razdoblju, (2) taktičke ciljeve, koji detaljnije razrađuju strateške ciljeve i sadrže nastojanja pojedinih organizacijskih dijelova knjižnice (primjerice, posudbeni odjel, odjel nabave, razmjene i obrade, služba čitaonice itd.), te (3) operativne ciljeve, koji detaljnije razrađuju taktičke ciljeve unutar nižih organizacijskih dijelova, primjerice radnih grupa, projektnih timova ili radnih mjesta. ${ }^{6}$

Iz pojedinih skupina ciljeva izvode se odgovarajuće strategije rada koje općenito određuju kako knjižnica planira ostvariti svoje strateške ciljeve koristeći raspoložive resurse te poslujući u konkretnom društvenom, ekonomskom, kulturnom i drugom okruženju.

Strategije knjižnica odnose na sve aspekte poslovanja, dakle i na knjižnične i neknjižnične djelatnosti, tijekom duljeg razdoblja, primjerice pet ili više godina. Strateški su planovi dokumenti koje je usvojilo nadležno tijelo upravljanja knjižnice i u kojem su detaljno razrađeni strateški ciljevi koje knjižnica treba u zada-

\footnotetext{
5 Primjerice, Knjižnice grada Zagreba imaju sljedeću izjavu o svojoj misiji: „Informirati, educirati, poticati i povezivati: podržavati kulturni, društveni i ekonomski razvoj naše zajednice, pružati usluge, osiguravati i braniti pravo na čitanje i slobodan pristup znanju, biti uvažavan i poželjan partner, poznat po izvrsnosti usluga, brižno njegovanim odnosima i zaštiti interesa naših korisnika, našeg osnivača, naših suradnika i naših djelatnika.“ Knjižnice grada Zagreba. Misija, vizija i strategija. [citirano: 2020-10-30]. Dostupno na http://www.kgz.hr/hr/o-nama/misija-vizija-i-strategija/222/.

6 Usp. Sikavica, P.; F. Bahtijarević-Šiber; N. Pološki Vokić. Temelji menadžmenta. Zagreb: Školska knjiga, 2008. Str. 155.
} 
nom roku postići. Kao primjere moguće je navesti Strategiju IFLA-e za razdoblje između 2019. i 2024. godine, koju je donijela Međunarodna federacija knjižničarskih društava i ustanova (IFLA) ${ }^{7}$ ili Strateški plan gradske i sveučilišne knjižnice Osijek 2016. - 2020. ${ }^{8} \mathrm{~S}$ druge strane, u praksi postoje strategije koje su usredotočene na posebna područja, primjerice Strategija za javno zagovaranje HKD-a 2015. - 2020. ${ }^{9}$ Strategije su, prema tome, temeljni operativni alati u realizaciji glavnih ciljeva knjižnica, predstavljaju osnovni okvir oblikovanja poslovne i organizacijske budućnosti te su sadržaj strateških planova. Za razliku od strategija, odnosno strateških planova, operativni planovi odnose se na jednu poslovnu godinu u kojoj su ciljevi strateškog plana razrađeni na operativne ciljeve i konkretne zadaće nižih organizacijskih jedinica. Tijekom provođenja operativnih ciljeva i zadataka, koji su sadržaj operativnih planskih dokumenata, moguće ih je tijekom planskog razdoblja u razumnoj mjeri korigirati i međusobno usklađivati, kako bi se glavni, odnosno strateški ciljevi učinkovitije ostvarivali.

Osim uobičajenih planskih dokumenata kao što su strateški i operativni planovi, u poslovanju knjižnica koriste se i određeni planski alati kao što su programi, projekti i proračuni. Za njih se može reći da predstavljaju planske dokumente u užem smislu.

Programi i projekti planski su dokumenti koji se u praksi ponekad ne razlikuju dovoljno. Prema Vodiču kroz znanje o upravljanju projektima

„(...) program se definira kao grupa povezanih projekata kojima se koordinirano upravlja kako bi se postigle koristi i kontrola koje se ne mogu postići njihovim pojedinačnim upravljanjem. Programi mogu uključivati elemente povezanog rada koji je izvan opsega zasebnih projekata iz programa. Projekt može, ali ne mora biti dio nekog programa, ali program uvijek ima projekte. ${ }^{10} \mathrm{Za}$ razliku od programa, projekt je vremenski ograničen pothvat poduzet radi stvaranja jedinstvenog proizvoda, usluge ili rezultata."11

Prema tome, programi su u pravilu opsežniji, složeniji i vremenski dulji oblici planiranja u odnosu na projekte.

\footnotetext{
7 Strategija IFLA-e za razdoblje 2019. - 2024. (IFLA Strategy 2019 - 2024) usmjerena je na četiri područja: (1) jačanje globalnog glasa knjižnica, (2) inspiriranje i poboljšanje profesionalne prakse, (3) povezivanje i jačanje te (4) optimiziranje organizacije. [citirano: 2020-10-30]. Dostupno na https://www.ifla.org/files/assets/hq/gb/strategic-plan/ifla-strategy-2019-2024-en.pdf.

8 Strateški plan gradske i sveučilišne knjižnice Osijek 2016. - 2020. [citirano: 2020-10-30]. Dostupno na http://www.gskos.unios.hr/wp-content/uploads/2017/02/Strategija-GISKO-2016_-2020_.pdf.

9 Hrvatsko knjižničarsko društvo. Strategija za javno zagovaranje HKD-a 2015. - 2020. [citirano: 2020-10-30]. Dostupno na https://www.hkdrustvo.hr/hr/dokumenti/kategorija/ostalo/.

10 Vodič kroz znanje o upravljanju projektima (Vodič kroz PMBOK). 4. izdanje. Zagreb: Mate 2011. Str. 9.

11 Isto, str. 443.
} 
Kao primjer prethodne podjele moguće je navesti Program 65 plus u organizaciji Knjižnica grada Zagreba, koji objedinjuje sedam međusobno poveznih projekata: Knjigom do vrata, Slikosat, Sat informacijske pismenosti, Susreti generacija, Učionica bez granica, Izložba 65 plus i Vježbaonica. ${ }^{12}$ Drugi primjer odnosa projekta i programa jest projekt Digitalne knjižnice za lokalni razvoj koji provodi Institut za razvoj i inovativnost mladih (IRIM) iz Zagreba u partnerstvu s INNOVABRIDGE Foundation iz Švicarske, a projekt se provodi kroz švicarsko-hrvatski program suradnje. ${ }^{13}$

Proračuni (budžeti) su planovi kojima se iskazuju očekivani prihodi i rashodi određenog budućeg razdoblja, najčešće jedne godine. U poslovanju knjižnica najčešće se koriste dva oblika proračuna: (1) planiranje godišnjih prihoda i rashoda prilikom izrade godišnjih financijskih planova i (2) planiranje financijskog tijeka projekata. Osim što su vrlo učinkoviti alati u planiranju financijskih sredstava, financijskog tijeka, odnosno likvidnosti, proračuni su nezaobilazni u procesima kontrole trošenja sredstava, bilo faznih ili završnih kontrola. Njihova izrada, usvajanje i provedba regulirani su odgovarajućim propisima koji se odnose na računovodstvo proračuna i proračunskih korisnika. ${ }^{14}$

\subsection{Planiranje regulacijskih funkcija u knjižnici}

Za razliku od planskih dokumenata koji su povezane s operativnim funkcijama knjižnice, regulacijske funkcije povezane su s dokumentima koji omogućavaju uspješno donošenje programiranih i neprogramiranih odluka u području poslovanja knjižnice, njezinih resursa, kao i u području odnosa knjižnice s njezinim unutarnjim i vanjskim okruženjem. U skupinu regulacijskih dokumenata ubrajaju se poslovne i njima srodne politike, pravila, procedure, programi, projekti, proračuni, kodeksi i drugi slični dokumenti.

Politike se mogu opisati kao „unaprijed određene vodilje koje usmjeravaju mišljenja i akcije prema postavljenim ciljevima. Svrstavaju se u stalne planove.“15

12 Knjižnice grada Zagreba. 65 plus. [citirano: 2020-10-30]. Dostupno na http://www.kgz.hr/ hr/65-plus-1296/1296. Napomena: na navedenoj mrežnoj stranici termini program i projekt ne koriste se sukladno usvojenoj međunarodnoj standardnoj terminologiji Project Management Institute, Ind. (PMI).

13 Digitalne knjižnice za lokalni razvoj - DL4LD. [citirano: 2020-10-30]. Dostupno na https:// croatianmakers.hr/hr/d14ld/.

14 Usp. Pravilnik o proračunskom računovodstvu i računskom planu. // Narodne novine 124, 2374(2014). [citirano. 2021-02-01]. Dostupno na: https://narodne-novine.nn.hr/clanci/sluzbeni/2014_10_124_2374.html. Taj temeljni tekst pravilnika doživio je i brojne izmjene $(115 / 15$, $87 / 16, \overline{3 / 18}, 126 / 19$ i 108/20.); Osim njega, važan je dokument i Pravilnik o financijskom izvještavanju u proračunskom računovodstvu. // Narodne novine 3, 59(2015). [citirano. 2021-02-01]. Dostupno na: https://narodne-novine.nn.hr/clanci/sluzbeni/2015_01_3_59.html. I taj je Pravilnik doživio svoje izmjene (93/15, 135/15, 2/17, 28/17, 112/18 i 126/19).

15 Politika. Leksikon menadžmenta. / ur. F. Bahtijarević-Šiber, P. Sikavica. Zagreb: Masmedia, 2001. Str. 415. 
Prema tome, poslovne politike određuju okvire unutar pojedinih poslovnih područja u kojima je potrebno donositi odluke. One mogu biti pisane i nepisane. Kao primjer pisanih politika moguće je navesti Politiku nabave građe i izgradnju zbirki u narodnim knjižnicama ${ }^{16}$ ili Politiku zaštite knjižnične građe u Knjižnici Filozofskog fakulteta u Osijeku ${ }^{17}$ itd. Nepisane politike, ponekad nazvane organizacijskom praksom, naslanjaju se na niz odluka rukovodstva koje su međusobno konzistentne, stvarajući opće smjernice u donošenju istih ili sličnih odluka. Za razliku od pravila, poslovne politike nemaju tvrde ili oštre granice okvira odlučivanja te ne pružaju čvrste obrasce odlučivanja. U tom smislu pojedine poslovne politike u knjižnicama trebaju otvarati i proširivati prostore inicijative i kreativnosti unutar pojedinih poslovnih područja, primjerice odnosa s javnošću, razvoja pojedinih djelatnosti, razmjene, suradnje i partnerstva itd.

Za razliku od politika, pravila nalažu ili zabranjuju određena postupanja te onemogućavaju arbitrarno odlučivanje. Nadležna upravna vijeća u knjižnicama donose normativne akte kojima utvrđuju pravila postupanja u određenom području poslovanja. Tako upravna vijeća unaprijed određuju buduće odluke koje donose nadležni subjekti odlučivanja i izvršavanja u knjižnici, primjerice ravnatelji, voditelji pojedinih službi, knjižničari, referenti, stručni suradnici, odnosno svi zaposlenici.

Procedure ili postupci planovi su kojima su unaprijed precizno utvrđeni koraci postupanja u određenim budućim aktivnostima. Zadanim vremenskim slijedom međusobno povezanih postupaka, planski se reguliraju složenija postupanja, primjerice posudbe knjiga, blagajničko poslovanje, izdavanja i obračuna putnih naloga itd. Procedurama se detaljnije uređuju pravila postupanja, definiraju se sudionici i navode se njihove ovlasti i odgovornosti, propisuju se obrasci i formulari te uređuju druga pitanja koja olakšavaju obavljanje i kontrolu određenih poslovnih aktivnosti.

\subsection{Ostali aspekti planiranja}

Prije početka procesa planiranja poslovanja knjižnice potrebno je izabrati metode i pristupe planiranju, primjerice metodologiju planiranja, izbor potrebnih informacija i vrste planova, odrediti subjekte odgovorne za planiranje itd.

(1) Izborom odgovarajuće metodologije planiranja i izrade planskih dokumenata određuje se redoslijed faza planiranja i odabiru se postupci i tehnike pomoću kojih će se utvrđivati pojedini parametri potrebni za planiranje.

\footnotetext{
16 Okvir smjernica za izradu pisane politike nabave građe i izgradnje zbirki u narodnim knjižnicama. [citirano: 2020-10-30]. Dostupno na http://maticna.nsk.hr/wp-content/uploads/2019/04/ smjernice-za-nabavu.pdf.

17 Politika zaštite knjižnične građe u Knjižnici Filozofskog fakulteta u Osijeku. [citirano: 202010-30]. Dostupno https://www.hkdrustvo.hr/zastita/wp-content/uploads/2016/03/Politika-za$\%$ c5\%a1 tite-knji\%c5\%beni\%c4\%8dne-gra\%c4\%91e-u-Knji\%c5\%benici-Filozofskog-fakulteta-u-Osijeku.pdf.
} 
Najčešći je redoslijed procesa planiranja sljedeći: (a) analiza unutarnjeg i vanjskog okruženja, (b) postavljanje poslovnih ciljeva (strateških i operativnih), (c) određivanje poslovnih politika na temelju kojih će se ostvarivati poslovni ciljevi, (d) usvajanje planskog dokumenta te (e) praćenje ostvarivanja usvojenog plana s potrebnim korekcijama, usklađivanjima, rebalansima itd.

Postupci planiranja odnose se na načine utvrđivanja ili pribavljanja izabranih dijelova plana, primjerice postupak anketiranja korisnika knjižnice o zadovoljstvu knjižničnim uslugama. Tehnike planiranja predstavljaju dijelove postupaka planiranja kojima subjekti planiranja utvrđuju određene ključne podatke ili pokazatelje, primjerice stopu rasta knjižničnog fonda ili obrazovnu strukturu knjižničara. Prema tome, metode, postupci i tehnike planiranja različiti su pojmovi koji se u praksi nerijetko koriste pogrešno.

(2) Prije početka planiranja potrebno je odrediti hoće li planiranje biti tradicionalno, odnosno odozgo prema dolje (centralizirano planiranje) ili odozdo prema gore (demokratsko planiranje) ili će ono biti tzv. susretno planiranje - istovremeno odozgo prema dolje i odozdo prema gore (pregovaračko planiranje). U prvom slučaju planiranje se temelji na strateškim ciljevima koje je utvrdilo upravno vijeće knjižnice, dok se u drugom slučaju planiranje temelji na ciljevima koje su postavile hijerarhijske niže organizacijske jedinice. Susretno planiranje ima brojne prednosti u odnosu na prethodna dva, ali traži veći organizacijski napor i vremenski je zahtjevnije.

(3) Nadalje, prije početka planiranja potrebno je odrediti koji će se sve parcijalni planovi priređivati, primjerice planovi nabave knjižnične građe, planovi tekućeg i investicijskog održavanja, razvojni planovi, planovi obrazovanja knjižničara i ostalih uposlenika, planovi za izvanredne i krizne situacije itd. Takvi parcijalni planovi učinkovito su sredstvo praćenja ostvarivanja postavljenih strateških i operativnih ciljeva knjižnice.

(4) Izborom planskih dokumenata koji će se izrađivati, određuju se podaci i informacije potrebni u njihovoj izradi. Izborom podataka i informacija određuju se čimbenici koji će se koristiti u ocjenjivanju uspješnosti realizacije pojedinih operativnih ciljeva. Također, potrebno je odrediti iz kojih će se izvora izabrani podaci i informacije pribavljati, tko će ih osiguravati, kako će se razmjenjivati i procesuirati.

(5) U organizacijskom smislu potrebno je odrediti subjekte planiranja, odnosno odrediti tko će operativno priređivati planske dokumente. Hoće li to biti posebna služba ili imenovana radna skupina, projektni tim ili neka kombinacija navedenih subjekata. Nakon što se planski dokumenti izrade, utvrđuje ih nadležni rukovoditelj, odnosno ravnatelj knjižnice te ih dostavlja nadležnom tijelu koje upravlja knjižnicom, odnosno upravnom vijeću knjižnice, na usvajanje. 


\section{Strateški plan knjižnice}

Strateško planiranje organizacijskog funkcioniranja knjižnice određuje njezinu misiju i viziju, strateške ciljeve, usklađujući ih s raspoloživim resursima i okolnostima koje su prisutne u unutarnjem i vanjskom okruženju. Prema tome, strateški planovi knjižnice sadrže opće i dugoročne organizacijske ciljeve koje nositelji funkcija upravljanja i rukovođenja namjeravaju ostvariti u budućnosti harmonizirajući ih s raspoloživim resursima i usklađujući ih sa svojim okruženjem.

Planiranje strateškog razvoja knjižnice svakako treba započeti s razmatranjem općih dokumenata koje su donijela nadležna regulacijska tijela. Primjerice, Ministarstvo kulture Republike Hrvatske u dokumentu Strateški plan Ministarstva kulture 2019. - 2021. iz 2018. godine u posebnom cilju 1.5. Razvoj književno-nakladničke i knjižnične djelatnosti navodi načine (ili mjere) potrebne za ostvarivanje navedenog posebnog cilja. Mjera 1.5.3., koja se odnosi na knjižničarstvo, glasi: „Potpora razvoju knjižničnih usluga i zadovoljavanju potreba korisnika." Za pokazatelje rezultata provođenja navedene mjere (ili indikatora) navodi se: ,(1) povećanje sredstava za nabavu knjižne i neknjižne građe za bibliobusne službe, (2) povećanje udjela sredstava za razvojne programe u knjižničnoj djelatnosti i (3) povećanje broja akcija i manifestacija u knjižnicama koje njeguju i razvijaju čitalačku kulturu“. ${ }^{18}$

Drugi razvojni dokument nacionalne razine koji je potrebno konzultirati tijekom strateškog planiranju knjižnice odnosi se na Strategiju hrvatskog knjižničarstva 2018. - 2022. godine. Taj je dokument usvojilo Hrvatsko knjižnično vijeće, dok je pripadajući Akcijski plan razvoja hrvatskog knjižničarstva (uvod i rizici) 2018. - 2022. godine usvojen u obliku nacrta i proslijeđen Ministarstvu kulture Republike Hrvatske na daljnji postupak. ${ }^{19}$ U Strategiji hrvatskog knjižničarstva 2018. - 2022. godine nalaze se sljedeći strateški ciljevi s 14 pratećih mjera njihove provedbe: „(1) razvijanje temeljnih i inovativnih knjižničnih usluga; (2) uspostava učinkovite i funkcionalne mreže knjižnica povezanih u jedinstveni nacionalni knjižnični informacijski sustav; (3) osiguranje ravnomjerne infrastrukturne pretpostavke za obnavljanje knjižnične djelatnosti; (4) utvrđivanje kompetencijskih okvira stručnih znanja i vještina djelatnika u knjižničarstvu“.

Nadalje, prilikom donošenja strateškog plana knjižnice preporučljivo je uzeti u obzir i sljedeće dokumente nacionalne razine, koje još nije razmatralo Hrvat-

18 Strateški plan ministarstva kulture 2019. - 2021. [citirano: 2020-10-3]. Dostupno na: https:// www.min-kulture.hr/userdocsimages/2005/Strate\%C5\%A1ki\%20plan\%20MK\%202019.2021.\%20-\%20Final\%20(004).pdf. Ovdje se, zbog ograničenog prostora, ne osvrćemo se na sadržaj navedenog dokumenta u odnosu na knjižničnu djelatnost, ali bi navedene mjere i pokazatelje bilo korisno analizirati.

19 Hrvatsko knjižnično vijeće. Strategija hrvatskog knjižničarstva 2018. - 2022. Sjednica od 20. svibnja 2017. godine. [citirano: 2020-10-3]. Dostupno na: https://min-kulture.gov.hr/kulturne-djelatnosti-186/knjiznicna-djelatnost-361/hrvatsko-knjiznicno-vijece-522/biljeske-sa-sjednica-663/arhiva-2031/2031. 
sko knjižnično vijeće: Strategiju razvoja narodnih knjižnica Republike Hrvatske 2016. - 2020., ${ }^{20}$ Strategiju razvoja sveučilišnih knjižničnih sustava u Republici Hrvatskoj: 2013. - 2015. godine, ${ }^{21}$ Strategiju razvoja specijalnih knjižnica u Republici Hrvatskoj: 2013. - 2015. ${ }^{22}$ itd. Ti dokumenti, u kojima su navedeni opći strateški ciljevi i mjere, nezaobilazna su polazišta u izradi strateških dokumenata pojedinačnih knjižnica kako narodnih, školskih, visokoškolskih tako i znanstvenih ili specijalnih.

U praksi planiranja rada knjižnica u Republici Hrvatskoj mogu se pronaći strateški planovi određenih užih područja djelovanja, primjerice javnog zagovaranja (Strateško planiranje i javnozagovaračke aktivnosti Knjižnica grada Zagreba ${ }^{23}$ ili Strategija za javno zagovaranje HKD-a 2015. - 2020. godine, ${ }^{24}$ odnosno Strategija javnog zagovaranja za visokoškolske knjižnice ${ }^{25}$ ) kao i za posebne knjižnice unutar mreže narodnih knjižnica (Strategija razvoja središnjih knjižnica nacionalnih manjina unutar mreže narodnih knjižnica, ${ }^{26}$ odnosno Strateško planiranje $i$ razvoj projekata vezanih za specifične djelatnosti muzejske knjižnice). ${ }^{27}$

Razmatrajući kvalitetu strateških planova knjižnica uputno je osvrnuti se na istraživanje objavljeno 2008. godine u kojem Jurić, na temelju odabranih parametara, zaključuje kako su „knjižnice“, u svojim strateškim planovima, „sposobne stvarati nove programe i usluge, međusobno se umrežavati i ostvarivati nove tipove suradnje“. U odnosu na glavne probleme strateškog planiranja u knjižnicama

20 Nacrt Strategije razvoja Hrvatskog knjižničarstva 2016. - 2020. [citirano: 2020-10-3]. Dostupno na: https://esavjetovanja.gov.hr/ECon/MainScreen?entityId=1850.

21 Strategije razvoja sveučilišnih knjižničnih sustava u Republici Hrvatskoj: 2013. - 2015. [citirano: 2020-10-3]. https:/www.nsk.hr/wp-content/uploads/2013/05/Strategija-razvoja-SKS.pdf.

22 Strategija razvoja specijalnih knjižnica u Republici Hrvatskoj: 2013. - 2015. [citirano: 202010-3]. Dostupno na: https:/www.nsk.hr/wp-content/uploads/2012/12/Strategija-razvoja-specijanih-knjiznica_web.pdf.

${ }_{23}$ Belan-Simić, A.; I. Đukec Kero. Strateško planiranje javnozagovaračke aktivnosti knjižnica Grada Zagreba. // Vjesnik bibliotekara Hrvatske 58, 1-2(2015), 29-44. [citirano: 2020-10-30]. Dostupno na https://www.hkdrustvo.hr/vjesnik-bibliotekara-hrvatske/index.php/vbh/article/view/52.

24 Hrvatsko knjižničarsko društvo. Strategija za javno zagovaranje HKD-a 2015. - 2020. [citirano: 2020-10-30]. Dostupno na https://www.hkdrustvo.hr/datoteke/1746.

25 Bačić, E. Strategija javnog zagovaranja za visokoškolske knjižnice. // Vjesnik bibliotekara Hrvatske 56, 4(2013), 53-65. [citirano: 2020-10-30]. Dostupno na https://www.hkdrustvo.hr/vjesnik-bibliotekara-hrvatske/index.php/vbh/article/view/139.

26 Todorčev Hlača, K. Strategija razvoja središnjih knjižnica nacionalnih manjina unutar mreže narodnih knjižnica. // Vjesnik bibliotekara Hrvatske 58, 1-2(2015), 45-66. [citirano: 2020-1030]. Dostupno na https://www.hkdrustvo.hr/vjesnik-bibliotekara-hrvatske/index.php/vbh/article/ view/53.

${ }^{27}$ Kalanj, K. Strateško planiranje i razvoj projekata vezanih za specifične djelatnosti muzejske knjižnice: Knjižnica Tehničkog muzeja u Zagrebu. // Vjesnik bibliotekara Hrvatske 58, 1-2(2015), 15-28. [citirano: 2020-10-30]. Dostupno na https://www.hkdrustvo.hr/vjesnik-bibliotekara-hrvatske/index.php/vbh/article/view/51. 
Jurić navodi „nekoherentnost i nerealnost ciljeva, izradu proračuna knjižnice te slab marketing“. ${ }^{28}$

Kasnija istraživanja strateških planova zaključuju da u promatranom broju hrvatskih knjižnica postoji svijest o važnosti strateškog planiranja, da strateški planovi sadrže sve ili većinu obveznih dijelova te da su većinom ispravno razrađeni. Prema mišljenju I. Kavića i R. Vrane broj strateških planova, međutim, nije dovoljno kvalitetan premda se može očekivati da će njihova kvaliteta rasti. ${ }^{29}$

Strateško planiranje razvoja knjižnice ima brojne organizacijske koristi. Moguće je navesti nekoliko najznačajnijih: (1) postiže se uspješnije upravljanje ustanovom i učinkovitije rukovođenje organizacijskim strukturama, (2) bolje se iskorištavaju postojeći resursi jer se učinkovitije pronalaze unutarnje neiskorištene rezerve; (3) povećava se prilagodljivost knjižnice promjenjivim okolnostima okruženja, (4) organizacija i koordinacija rada pojedinih organizacijskih jedinica i radnih mjesta kontinuirano se obnavlja i međusobno usklađuje, (5) kontrola poslovanja postaje moguća jer je moguće uspoređivati planirane i ostvarene ciljeve, (6) smanjuju se rizici nastupanja neželjenih događaja i smanjuje se opća neizvjesnost poslovanja, (7) organizacijski razvoj knjižnice cjelovit je i uravnotežen itd. ${ }^{30}$

\subsection{Uobičajena struktura sadržaja strateškog plana knjižnice}

Preporučena je struktura sadržaja strateškog plana knjižnice sljedeća: (1) osnovni podaci o knjižnici, (2) izjava o misiji, viziji i temeljnim vrijednostima, (3) politika osiguranja kvalitete, (4) procjena vanjskog okruženja, (5) pregled dosadašnjeg rada knjižnice, (6) opći strateški i posebni ciljevi, (7) ključni pokazatelji uspješnosti provedbe strategije i (8) zaključak.

Izbor strateških ciljeva knjižnica treba se odnositi na sve djelatnosti knjižnice, knjižnične i neknjižnične. Međutim, razmatrajući domaću praksu može se zaključiti da strateški planovi najčešće sadrže samo dugoročne ciljeve knjižničnih djelatnosti, dok su ciljevi neknjižničnih djelatnosti u njima prisutni ili rijetko ili su potpuno odsutni. ${ }^{31} \mathrm{U}$ istraživanju narodnih knjižnica u Republici Hrvatskoj, koje je 2016. godine provela Ljiljana Poljak, utvrđeno je da u strateškim planovima knjižnica dominiraju sljedeći strateški ciljevi: izgradnja i razvoj zbirki, kulturni

\footnotetext{
28 Jurić, M. Rezultati evaluacije: knjižnice. // Organizacijski razvoj i strateško planiranje u kulturi: Grad Zagreb / urednici Sanjin Dragojević, Tihomir Žiljak. Zagreb: Pučko otvoreno učilište, 2008. Str. 199-200.

29 Katavić, I.; R. Vrana. Strateški planovi hrvatskih i inozemnih knjižnica: sličnosti i razlike. // Vjesnik bibliotekara Hrvatske 61, 1(2018), 287-320. [citirano: 2020-10-30]. Dostupno https:// hrcak.srce.hr/file/303896., str. 301.

30 Usp. Sikavica, P.; F. Bahtijarević-Šiber; N. Pološki Vokić. Nav. dj., str. 141-143.

31 Istraživanje Katavić i Vrane, osim što implicitno podupire prethodnu tvrdnju, u zaključku navodi važna obilježja strateškog planiranja i usvojenih strateških planova narodnih knjižnica u Hrvatskoj u usporedbi s uzorkom inozemnih knjižnica. Usp. Katavić, I.; R. Vrana. Nav. dj.
} 
razvoj, cjeloživotno učenje, knjižnica kao kulturno središte, poticanje različitosti (multikulturalnost), učenje (poticanje, mjesto za učenje), popularizacija knjige i čitanja, zavičajna zbirka, $e$-knjige (nabava digitalne građe), digitalizacija, promicanje pismenosti (uključujući i informacijsku), stalno stručno usavršavanje knjižničnih djelatnika, poticanje kreativnosti, alternativni izvori financiranja, promicanje kulturnih i civilizacijskih vrijednosti, sustav za vrednovanje rada knjižnice, osiguravanje besplatnog korištenja usluga, razvoj službi i usluga za korisnike, automatizacija i informatizacija poslovanja. ${ }^{32}$ Navedeni rezultati istraživanja pokazuju da dominiraju strateški ciljevi knjižničnih djelatnosti, dok su ciljevi neknjižničnih djelatnosti uglavnom zanemareni.

Primjeri strateških ciljeva koji bi mogli biti uvršteni u strateške planove razvoja knjižnica, a odnose se na neknjžnične djelatnosti jesu: (1) razvoj upravljanja, rukovođenja i organizacije poslovanja, (2) izgradnja sustava upravljanja kvalitetom, (3) razvoj društvene uloge knjižnice, odnosno povezanosti knjižnice s dionicima, (4) dugoročno održivo i financijski stabilno poslovanje.

Opći strateški ciljevi u strateškim planovima zatim se razrađuju na posebne (ili specifične) ciljeve, a svakom se posebnom strateškom cilju pridružuje određeni broj operativnih zadaća (ili mjera). Tako se općem strateškom cilju koji se odnosi na razvoj upravljanja, rukovođenja i organizaciju poslovanja mogu pridružiti sljedeći posebni (ili specifični) ciljevi: (1) kontinuirano vrednovanje organizacijskog ustroja, (2) osiguravanje uspješnog sustava upravljanja i rukovođenja, (3) uspostava integralnog informacijsko-komunikacijskog sustava, (4) ustroj učinkovitog poslovanja, (5) izgradnja institucijskog identiteta knjižnice itd.

Općem strateškom cilju koji se odnosi na izgradnju sustava upravljanja kvalitetom mogu se pridružiti sljedeći posebni (ili specifični) ciljevi: (1) revidiranje i poboljšavanje postojećih dokumenata i procedure praćenja i razvijanja kvalitete svih područja rada knjižnice, (2) unaprjeđivanje mehanizama praćenja kvalitete rada, (3) unaprjeđivanje kompetencije nositelja sustava upravljanja kvalitetom, (4) razvijanje organizacijske kulture kvalitete itd.

Općem strateškom cilju koji se odnosi na razvoj društvene uloge knjižnice, odnosno njezine povezanosti s dionicima, mogu se pridružiti sljedeći posebni (ili specifični) ciljevi: (1) informiranje javnosti o radu i postignućima knjižnice, (2) kontinuirano razvijanje suradnje s dionicima iz neposrednog okruženja, (3) održavanje javnih tribina, okruglih stolova, javnih predavanja i slično.

Općem strateškom cilju koji se odnosi na dugoročno održivo i financijski stabilno poslovanje mogu pridružiti sljedeći posebni (ili specifični) ciljevi: (1) očuvati likvidnost poslovanja knjižnice, (2) poslovati na dugoročno održiv način itd.

32 Poljak, L. Strateško planiranje u narodnim knjižnicama u Hrvatskoj: diplomski rad. Zadar: Odjel za informacijske znanosti Sveučilišta, 2016. Str. 55. 
Navedene primjere općih strateških ciljeva i njima pridruženih posebnih (ili specifičnih) neknjižničnih strateških ciljeva možemo pregledno prikazati u tablici 1.

Tablica 1. Opći i specifični strateški ciljevi ${ }^{33}$

\begin{tabular}{|c|c|c|}
\hline $\begin{array}{l}\text { Red. } \\
\text { broj }\end{array}$ & $\begin{array}{l}\text { Opći strateški } \\
\text { ciljevi }\end{array}$ & Posebni strateški ciljevi \\
\hline 1. & $\begin{array}{l}\text { Razvoj } \\
\text { upravljanja, } \\
\text { rukovođenja } \\
\text { i organizacije } \\
\text { knjižnice }\end{array}$ & $\begin{array}{l}\text { 1.1. Kontinuirano vrednovanje organizacijskog ustroja } \\
\text { 1.2. Osiguravanje uspješnog sustava upravljanja i } \\
\text { rukovođenja } \\
\text { 1.3. Uspostava integralnog informacijsko- } \\
\text { komunikacijskog sustava } \\
\text { 1.4. Ustroj učinkovitog poslovanja } \\
\text { 1.5. Izgradnja institucijskog identiteta knjižnice itd. }\end{array}$ \\
\hline 2. & $\begin{array}{l}\text { Izgradnja sustava } \\
\text { upravljanja } \\
\text { kvalitetom } \\
\text { knjižnice }\end{array}$ & $\begin{array}{l}\text { 2.1. Revidiranje i poboljšavanje postojećih dokumenata } \\
\text { i procedura praćenja i razvijanja kvalitete svih } \\
\text { područja rada knjižnice } \\
\text { 2.2. Unaprjeđivanje mehanizama praćenja kvalitete rada } \\
\text { knjižnice } \\
\text { 2.3. Unaprjeđivanje kompetencije nositelja sustava } \\
\text { upravljanja kvalitetom rada knjižnice } \\
\text { 2.4. Razvijanje organizacijske kulture kvalitete rada } \\
\text { knjižnice itd. }\end{array}$ \\
\hline 3. & $\begin{array}{l}\text { Razvoj društvene } \\
\text { uloge knjižnice, } \\
\text { odnosno } \\
\text { povezanost } \\
\text { knjižnice s } \\
\text { dionicima }\end{array}$ & $\begin{array}{l}\text { 3.1. Informiranje javnosti o radu i postignućima } \\
\text { knjižnice } \\
\text { 3.2. Kontinuirano razvijanje suradnje s dionicima iz } \\
\text { neposrednog okruženja } \\
\text { 3.3. Održavanje javnih tribina, okruglih stolova, javnih } \\
\text { predavanja i slično, tijekom kojih se unaprjeđuje } \\
\text { javna predodžba o društvenoj ulozi knjižnice. }\end{array}$ \\
\hline 4. & $\begin{array}{l}\text { Dugoročno } \\
\text { održivo i } \\
\text { financijski } \\
\text { stabilno } \\
\text { poslovanje } \\
\text { knjižnice }\end{array}$ & $\begin{array}{l}\text { 4.1. Očuvanje solventnosti i likvidnosti poslovanja } \\
\text { knjižnice } \\
\text { 4.2. Poslovanje na dugoročno održiv način } \\
\text { 4.3. Pribavljanje i održavanje alternativnih izvora } \\
\text { financijskih i drugih resursa. } \\
\text { Itd. }\end{array}$ \\
\hline 5. & \multicolumn{2}{|c|}{$\begin{array}{l}\text { U nastavku slijede opći strateški ciljevi koji se odnose na knjižnično } \\
\text { poslovanje. }\end{array}$} \\
\hline
\end{tabular}

Metodologija izrade strateških planova razvoja nalaže da se za svaki poseban (ili specifičan) cilj trebaju prirediti odgovarajuće zadaće kojima će se on realizi-

33 Tablice koje slijede rezultat su promišljanja autora. 
rati. Pri tome, za svaku zadaću treba navesti očekivani ishod, imenovati nositelje, odrediti pokazatelje učinaka (ili indikatora) te izabrati odgovarajuće mehanizme praćenja.

U nastavku moguće je navesti nekoliko primjera kao poticaj knjižnicama za unaprjeđenje vlastite prakse. Kod posebnog (specifičnog) strateškog cilja koji se odnosi na kontinuirano vrednovanje organizacijskog ustroja knjižnice mogu se navesti zadaće prikazane u tablici 2 .

Tablica 2. Prikaz zadaća u realizaciji posebnog strateškog cilja kontinuirano vrednovanje organizacijskog ustroja knjižnice

\begin{tabular}{|l|l|}
\hline Zadaća 1 & $\begin{array}{l}\text { Godišnja inventura i vrednovanje učinkovitosti } \\
\text { postojećih općih akata. }\end{array}$ \\
\hline Očekivani ishod & Kvalitetno polazište za unaprjeđenje kvalitete općih akata. \\
\hline Nositelji & $\begin{array}{l}\text { Upravno vijeće; ravnatelj knjižnice; knjižnično vijeće; } \\
\text { tajnik; predstojnici organizacijskih jedinica. }\end{array}$ \\
\hline Pokazatelj učinka & Broj internih vrednovanja učinkovitosti općih akata. \\
\hline Mehanizam praćenja & Zaključci i zapisnici održanih sjednica nadležnih tijela. \\
\hline
\end{tabular}

\begin{tabular}{|l|l|}
\hline Zadaća 2 & Evaluacija postojećih procedura i postupaka poslovanja. \\
\hline Očekivani ishod & $\begin{array}{l}\text { Kvalitetno polazište za unaprjeđenje kvalitete } \\
\text { postojećih procedura i postupaka poslovanja. }\end{array}$ \\
\hline Nositelji & $\begin{array}{l}\text { Ravnatelj; knjižnično vijeće; tajnik; predstojnici } \\
\text { organizacijskih jedinica knjižnice. }\end{array}$ \\
\hline Pokazatelj učinka & Broj unaprijeđenih procedura \\
\hline Mehanizam praćenja & Zaključci i zapisnici održanih sjednica nadležnih tijela. \\
\hline
\end{tabular}

\begin{tabular}{|l|l|}
\hline Zadaća 3 & $\begin{array}{l}\text { Izrada godišnjih izvješća knjižnice te izvješća } \\
\text { organizacijskih jedinica knjižnice. }\end{array}$ \\
\hline Očekivani ishod & $\begin{array}{l}\text { Učinkovita usporedba ostvarenih s planiranim } \\
\text { rezultatima rada. }\end{array}$ \\
\hline Nositelji & $\begin{array}{l}\text { Ravnatelj; knjižnično vijeće; predstojnici } \\
\text { organizacijskih jedinica knjižnice; rukovoditelji } \\
\text { stručnih službi i drugi. }\end{array}$ \\
\hline Pokazatelj učinka & $\begin{array}{l}\text { Utvrđene razlike između planiranih i realiziranih } \\
\text { operativnih ciljeva. }\end{array}$ \\
\hline Mehanizam praćenja & $\begin{array}{l}\text { Pojedinačna izvješća organizacijskih jedinica prema } \\
\text { zadanom formatu. }\end{array}$ \\
\hline
\end{tabular}


U primjeru posebnog (specifičnog) strateškog cilja koji se odnosi na razvoj uspješnog sustava upravljanja i rukovođenja knjižnicom mogu se navesti zadaće prikazane u tablici 3 .

Tablica 3. Prikaz zadaća u realizaciji posebnog strateškog cilja koji se odnosi na osiguranje uspješnog sustava upravljanja i rukovođenja knjižnicom

\begin{tabular}{|l|l|}
\hline Zadaća 1 & $\begin{array}{l}\text { Izrada i usvajanje godišnjeg operativnog plana } \\
\text { knjižnice te odgovarajućih planova ustrojbenih jedinica } \\
\text { knjižnice. }\end{array}$ \\
\hline Očekivani ishod & $\begin{array}{l}\text { Učinkovitije planiranje i usklađivanje operativne } \\
\text { izvedbe strateških ciljeva knjižnice. }\end{array}$ \\
\hline Nositelji & $\begin{array}{l}\text { Upravno vijeće; ravnatelj; knjižnično vijeće; predstojnici } \\
\text { odjela, rukovoditelji, voditelji ogranaka i drugi. }\end{array}$ \\
\hline Pokazatelj učinka & Pojedinačni planovi priređeni prema zadanom formatu. \\
\hline Mehanizam praćenja & $\begin{array}{l}\text { Priređeni godišnji planovi ustrojbenih jedinica i } \\
\text { godišnji plan knjižnice. }\end{array}$ \\
\hline Zadaća 2 & $\begin{array}{l}\text { Interna i eksterna usklađivanja općih normativnih akata } \\
\text { te izrada novih općih normativnih akata. }\end{array}$ \\
\hline Očekivani ishod & $\begin{array}{l}\text { Unaprijeđena međusobna usklađenost općih } \\
\text { normativnih akata knjižnica te njihova usklađenost sa } \\
\text { zakonima i drugim propisima RH. }\end{array}$ \\
\hline Nositelji & Ravnatelj; tajnik; predstojnici odjela. \\
\hline Pokazatelj učinka & $\begin{array}{l}\text { Izrađeni opći normativni akti: izmijenjeni, dopunjeni } \\
\text { ili novi. }\end{array}$ \\
\hline Mehanizam praćenja & Zapisnici sjednica nadležnih tijela, odluke, zaključci itd. \\
\hline Zadaća 3 & $\begin{array}{l}\text { Usklađivanje i poboljšavanje sustava upravljanja i } \\
\text { rukovođenja knjižnicom. }\end{array}$ \\
\hline Očekivani ishod & $\begin{array}{l}\text { Učinkovitije i uspješnije upravljanje i rukovođenje } \\
\text { radom knjižnice. }\end{array}$ \\
\hline Nositelji & $\begin{array}{l}\text { Upravno vijeće; ravnatelj; knjižnično vijeće; } \\
\text { predstojnici odjela; voditelji; rukovoditelji i drugi. }\end{array}$ \\
\hline Pokazatelj učinka & Usvojene odluke, upute i procedure. \\
\hline Mehanizam praćenja & Zapisnici sjednica nadležnih tijjela, odluke, zaključci itd. \\
\hline
\end{tabular}

U primjeru posebnog (specifičnog) strateškog cilja koji se odnosi na ustroj učinkovitog poslovanja knjižnice mogu se navesti zadaće prikazane u tablici 4. 
Tablica 4. Prikaz zadaća u realizaciji posebnog strateškog cilja koji se odnosi na ustroj učinkovitog poslovanja knjižnice

\begin{tabular}{|l|l|}
\hline Zadaća 1 & $\begin{array}{l}\text { Evaluacija postojećeg rada knjižničnih i stručnih službi } \\
\text { knjižnice. }\end{array}$ \\
\hline Očekivani ishod & $\begin{array}{l}\text { Kvalitetno polazište za određivanje mjera unaprjeđenja } \\
\text { kvalitete rada stručnih službi knjižnice. }\end{array}$ \\
\hline Nositelji & $\begin{array}{l}\text { Ravnatelj; knjižnično vijeće; tajnik; predstojnici odjela; } \\
\text { voditelji knjižničnih i stručnih službi. }\end{array}$ \\
\hline Pokazatelj učinka & $\begin{array}{l}\text { Interno vrednovanje učinkovitosti rada knjižničnih i } \\
\text { stručnih službi knjižnice. }\end{array}$ \\
\hline Mehanizam praćenja & Zapisnici i zaključci održanih sjednica. \\
\hline
\end{tabular}

\begin{tabular}{|l|l|}
\hline Zadaća 2 & Povećanje učinkovitosti rada knjižničnih i stručni službi. \\
\hline Očekivani ishod & $\begin{array}{l}\text { Unaprijeđena učinkovitost rada knjižničnih i stručnih } \\
\text { službi. }\end{array}$ \\
\hline Nositelji & $\begin{array}{l}\text { Ravnatelj; pomoćnik; tajnik; voditelji knjižničnih i } \\
\text { stručnih službi. }\end{array}$ \\
\hline Pokazatelj učinka & $\begin{array}{l}\text { Usvojene odluke, mjere i procedure o radu stručnih } \\
\text { službi. }\end{array}$ \\
\hline Mehanizam praćenja & $\begin{array}{l}\text { Zapisnici i zaključci održanih sjednica o donesenim } \\
\text { mjerama. Anketa korisnika o zadovoljstvu radom } \\
\text { knjižničnih i stručni službi. }\end{array}$ \\
\hline
\end{tabular}

\begin{tabular}{|l|l|}
\hline Zadaća 3 & $\begin{array}{l}\text { Stručno osposobljavanje zaposlenika knjižničnih i } \\
\text { stručnih službi u stručnom radu. }\end{array}$ \\
\hline Očekivani ishod & $\begin{array}{l}\text { Unaprijeđene kompetencije zaposlenika knjižničnih i } \\
\text { stručnih službi. }\end{array}$ \\
\hline Nositelji & Ravnatelj; knjižnično vijeće, tajnik. \\
\hline Pokazatelj učinka & $\begin{array}{l}\text { Program edukacije zaposlenika stručnih službi; } \\
\text { prezentacijski prikaz; izvješće o evaluaciji održanih } \\
\text { edukacija zaposlenika stručnih službi }\end{array}$ \\
\hline Mehanizam praćenja & $\begin{array}{l}\text { Godišnje izvješće knjižnice, pozivi na edukacije i popis } \\
\text { sudionika. }\end{array}$ \\
\hline
\end{tabular}

U primjeru posebnog (specifičnog) strateškog cilja koji se odnosi na izgradnju institucijskog identiteta knjižnice mogu se navesti zadaće prikazane u tablici 5. 
Tablica 5. Prikaz zadaća u realizaciji posebnog strateškog cilja koji se odnosi na izgradnju institucijskog identiteta knjižnice

\begin{tabular}{|c|c|}
\hline Zadaća 1. & Utvrđivanje i obilježavanje Dana knjižnice. \\
\hline Očekivani ishod & Doprinos izgradnji organizacijske kulture knjižnice. \\
\hline Nositelji & Upravno vijeće; knjižnično vijeće, ravnatelj; tajnik. \\
\hline Pokazatelj učinka & $\begin{array}{l}\text { Zajednička svečana sjednica Upravnog i Stručnog vijeća } \\
\text { na Dan knjižnice, uz prisustvo predstavnika osnivača } \\
\text { knjižnice, predstavnika korisnika, predstavnika ključnih } \\
\text { dionika te ostalih pozvanih uglednika. }\end{array}$ \\
\hline Mehanizam praćenja & $\begin{array}{l}\text { Godišnje izvješće knjižnice; pozivnica s programom } \\
\text { zajedničke svečane sjednice. }\end{array}$ \\
\hline Zadaća 2. & $\begin{array}{l}\text { Godišnja dodjela nagrada i priznanja zaposlenicima, } \\
\text { korisnicima, ključnim dionicima i vanjskim } \\
\text { suradnicima knjižnice na Dan knjižnice. }\end{array}$ \\
\hline Očekivani ishod & $\begin{array}{l}\text { Doprinos izgradnji organizacijske kulture knjižnice i } \\
\text { njezinog ugleda u zajednici. }\end{array}$ \\
\hline Nositelji & Upravno vijeće; ravnatelj; tajnik. \\
\hline Pokazatelj učinka & $\begin{array}{l}\text { Dodijeljene nagrade i priznanja najboljim } \\
\text { zaposlenicima, zaslužnim dionicima, korisnicima } \\
\text { te drugim uglednicima; dodjela stipendija i potpora } \\
\text { zaposlenicima za formalno i neformalno obrazovanje i } \\
\text { stručno usavršavanje. }\end{array}$ \\
\hline Mehanizam praćenja & $\begin{array}{l}\text { Godišnje izvješće knjižnice; pozivnica s programom } \\
\text { zajedničke svečane sjednice; popis laureata i popis } \\
\text { primatelja stipendije za cjeloživotno obrazovanje. }\end{array}$ \\
\hline
\end{tabular}

Slično se iz navedenih primjera posebnih (specifičnih) strateških ciljeva mogu razviti odgovarajuće zadaće s očekivanim ishodima, nositeljima, pokazateljima učinaka i mehanizmima praćenja.

Strateški planovi razvoja pojedinih vrsta knjižnica imaju svoje posebnosti. To se odnosi na knjižnice u sastavu, koje svoje planove razvoja usuglašavaju s ustanovom čiji su dio. Međutim, sve knjižnice, bez obzira kojoj vrsti pripadaju, u pripremi, izradi, usvajanju i implementiranju strateških planova imaju nekoliko zajedničkih obilježja: (1) uvijek postoji veća ili manja povezanost $\mathrm{s}$ osnivačima, (2) ekonomska snaga i razvijenosti gospodarstva utječe na oblikovanje razvojnih planova, (3) utjecaj političke volje i spremnosti osnivača i šire društvene zajednice na ulaganja u razvoj knjižnica i knjižničarstva, (4) uspješnost rukovodstva knjižnice u predstavljanju i promicanju vlastitih razvojnih planova i (5) sposobnost 
stručnih službi u pribavljanju i korištenju alternativnih izvora razvojnih sredstava, primjerice EU fondova. ${ }^{34}$

\subsection{Ključni pokazatelji uspješnosti provedbe strateškog plana}

Ključni pokazatelji uspješnosti provedbe strategije razvoja knjižnice (engl. key performance indicators - KPI) predstavljaju nezaobilazne mjerne alate koji daju vrijedne informacije potrebne ravnatelju, upravnom vijeću i knjižničnom vijeću o procesu ostvarivanja planiranih ciljeva. Njihov izbor ovisi o nadležnosti tijela koje donosi strateški plan razvoja, odnosno upravnog vijeća knjižnice. Moguće ih se razvrstati u nekoliko skupina: (a) korisnici, (b) zaposlenici, (c) imovina, financijska imovina i drugi resursi, (d) nakladnička djelatnost, (e) programi, projekti itd.

Ključni pokazatelji uspješnosti provedbe strategije imaju nešto uže područje nego statistički podaci o radu knjižnice. KPI imaju temeljnu svrhu praćenja ostvarivanja strateških ciljeva navedenih u strateškom planu razvoja knjižnice, dok statistički podaci i iz njih izvedeni pokazatelji daju detaljnije informacije potrebne za upravljanje i rukovođenje.

U nastavku teksta navodimo primjere mogućih ključnih pokazatelja uspješnosti provedbe strateškog plana knjižnice.

(a) Korisnici:

(1) broj godišnjih korisnika, ukupno, po odjelima i po ograncima

(2) broj upisanih i ispisanih korisnika, ukupno, po odjelima i po ograncima

(3) zadovoljstvo korisnika uslugama knjižnice, ukupno, po odjelima i po ograncima

(4) broj posuđenih jedinica knjižnog fonda, ukupno, pod odjelima, po ograncima itd.

(b) Zaposlenici:

(1) vrijednost ulaganja u formalno, neformalno i informalno obrazovanje knjižničnih i neknjižničnih zaposlenika, (primjerice zaposlenici koji su završili odgovarajući preddiplomski ili diplomski studij, ili program cjeloživotnog učenja i obrazovanje, ili sudjelovanja na stručnim ili znanstvenim skupovima itd.) te broj zaposlenika

\footnotetext{
34 O posebnostima strateškog planiranja pojedinih vrsta knjižnica u: Majstorović, Z;. V. Čelić-Tica; J. Leščić. Strategijski plan razvoja knjižnica: s posebnim osvrtom na zadaće Nacionalne i sveučilišne knjižnice u Zagrebu. // Vjesnik bibliotekara Hrvatske 56, 1-2(2013), 35-70. [citirano: 2020-10-30]. Dostupno na https://www.hkdrustvo.hr/vjesnik-bibliotekara-hrvatske/index. $\mathrm{php} / \mathrm{vbh} /$ article/view/182.
} 
(2) broj organiziranih stručnih radionica te broj polaznika

(3) broj zaposlenika koji su objavili stručnu ili znanstvenu publikaciju te broj publikacija itd.

(c) Imovina, financijska imovina i drugi resursi:

(1) financijski rezultati poslovanja knjižnice

(2) vrijednost ulaganja u nabavu, zamjenu i održavanje prostora, opreme, instalacija, infrastrukture te informacijsko-komunikacije tehnologije

(3) vrijednost ulaganja u bibliotečno-informacijske resurse

(4) vrijednost ulaganja u knjižnične fondove itd.

(d) Nakladnička djelatnost:

(1) broj objavljenih naslova knjiga i časopisa

(2) broj objavljenih naslova knjiga i časopisa u suizdavaštvu itd.

(e) Programi i projekti:

(1) broj programa tijekom godine

(2) broj projekata tijekom godine

(3) utrošena sredstva za programe i projekte

(4) broj korisnika pojedinih programa i projekata itd.

Navedeni pokazatelji odreda su kvantitativni (osim zadovoljstva korisnika, ali i oni se nastoje kvantificirati) i kao takvi jednodimenzionalne su prirode. Ekonomisti koji se bave planiranjem, a osobito statističari, vrlo su im skloni jer se brojevi i količine mogu pratiti, mjeriti, uspoređivati i prognozirati. Knjižnice su svojevrsni poslovni sustavi, ali u odnosu na poslovne sustave imaju značajnije i šire društvene uloge koje se teško kvantificiraju. Prema tome, uspješnost ostvarivanja plana strateškog razvoja knjižnice treba promatrati i s kvalitativnog stajališta. To znači da je potrebno imati u vidu i učinke koje je knjižnica svojim uslugama ostvarila u odnosu na svoje korisnike u pogledu njihovog informacijskog, obrazovnog, znanstvenog, istraživačkog, kulturnog i općeg društvenog napretka.

Mjerenje navedenih kvalitativnih ishoda nakon realizacije strateškog plana knjižnice moguće je, ali ima neznatnu operativnu ulogu u izradi strateškog plana. Takva mjerenja svakako imaju smisla u širim društvenim istraživanja na razini nacionalne ekonomije. Premda se vrednovanja kvalitativnih učinaka koje knjižnice imaju na svoje korisnike, a preko njih i na ostatak društva, teško mogu kvantitativno izraziti, potrebno ih je u strateškim planovima navoditi i tako postupno podizati javnu svijest o važnosti knjižnica i njihovoj društvenoj ulozi. ${ }^{35}$

35 U svome članku M. Mihalić razmatra pitanja o dosezima vrednovanja uspješnosti knjižnica ekonomskim pokazateljima. Vidjeti u: Mihalić, M. Mjere li samo pokazatelji uspješnosti vrijednost knjižnica?: prema vrednovanju društvenih ciljeva organizacija u kulturi. // Vjesnik bibliote- 


\section{Operativno ili godišnje planiranje rada knjižnice}

Nakon što su strateškim planom razvoja postavljani strateški ciljevi, a nakon njih određeni posebni (ili specifični) ciljevi te su im pridružene odgovarajuće zadaće, operativni ih planovi razrađuju na jednogodišnje razdoblje. ${ }^{36}$ Rezultat je operativnog ili godišnjeg planiranja dokument koji je strateške ciljeve konkretizirao na određena poslovna područja te ih povjerio organizacijskim jedinicama na izvršenje. Kao i kod strateškog planiranja razvoja knjižnice, operativno planiranje treba provoditi jednako na knjižničnim i neknjižničnim djelatnostima.

Godišnji operativni plan knjižničnih djelatnosti knjižnice najčešće se odnosi na: (1) nabavu knjižnične građe, (2) obradu knjižnične građe, (3) reviziju i otpis građe, (4) osiguranje pristupa online bazama podatka, (5) zaštitu knjižnične građe - preventivnu i kurativnu, (6) kulturne i promotivne aktivnosti knjižnice (primjerice, izložbe, kulturno-promotivne aktivnosti s djecom i mladima, predavanja, promocije, tribine, čitateljski klubovi, književni i drugi susreti itd.), (7) rad s korisnicima s posebnim potrebama, (8) bibliobus, (9) edukativne djelatnosti namijenjene korisnicima (primjerice, edukacije mrežnog pretraživanja, tečajevi jezika za umirovljenike itd.), (10) razvoj internetskog portala knjižnice, (11) suradnju s drugim knjižnicama u zemlji i inozemstvu, (12) planiranje izvedbe pojedinih programa i projekata, (13) nakladništvo knjižnice, (14) razvoj matične službe (ako je knjižnica matična) itd.

Knjižnice, kao i u slučaju izrade strateških planova razvoja, u manjoj se mjeri usredotočuju na neknjižnične djelatnosti nego na knjižnične. Da bi godišnji operativni plan knjižnice bio cjelovit, potrebno je u njemu planirati neknjižnične djelatnosti koje se najčešće odnose na: (1) financijski plan koji obuhvaća plan prihoda i plan rashoda, svaki s vlastitim stavkama, (2) plan nabave neknjižnične imovine, (materijalne i nematerijalne, primjerice energente, vodu, odvodnju, potrošne materijale, sitni inventar, opremu, vozila i nekretnine, računalne programe, osiguranje, pravne i druge usluge itd.), (3) plan popravaka, održavanja i investicijskog održavanja građevinskih objekata, opreme i instalacija, (4) plan ljudskih potencijala (broj i struktura potrebnih stručnih, administrativnih i tehničkih radnika, planiranje rada volontera i studenata na praksi, plan cjeloživotnog obrazovanja uposlenika itd.), (5) plan rada pojedinih organizacijskih jedinica, odnosno službi, primjerice informatičke službe, službe arhiva, nakladništvo, odnosi s javnošću itd., (5) planovi postupanja u kriznim događajima itd.

S obzirom na to da se poslovanje knjižnice temelji na stabilnosti prihoda, okosnicu godišnjeg planskog dokumenta, kao i svih njegovih dijelova, čini uravnoteženi financijski plan i iz njega izveden godišnji proračun. Drugim riječima,

kara Hrvatske 55, 1(2012), 29-44. [citirano: 2020-10-30]. Dostupno na https://www.hkdrustvo.hr/ vjesnik-bibliotekara-hrvatske/index.php/vbh/article/view/325.

36 Osmanagić Bedenik, N. Operativno planiranje. Zagreb: Školska knjiga, 2002. Str. 100. 
svi parcijalni planovi knjižnice moraju se kontinuirano usklađivati s financijskim planom i godišnjim proračunom, koji predstavljaju glavni instrument raspodjele raspoloživih financijskih sredstava.

Prihodi koje knjižnica prima od svog osnivača ili svojih osnivača, najčešće su dostatni za redovitu djelatnost ili, kako bi to ekonomisti rekli, za prostu reprodukciju. Sredstava za razvoj, ili za proširenu reprodukciju, u pravilu su skromna i najčešće razmjerno manja nego sredstva koja primaju druge društvene djelatnosti. ${ }^{37}$ Zato ravnatelji nekih knjižnica posežu za alternativnim izvorima prihoda kojima mogu djelomično osigurati organizacijski razvoj. To mogu biti prihodi od ključnih dionika s kojima se zaključuju odgovarajući ugovori o suradnji i izvedbi dogovorenih programa, zatim prihodi kojima se financiraju dodatni programi i projekti iz europskih fondova, sredstva sponzora i donatora itd.

\section{Planiranje upravljanja krizom}

Na početku ovog teksta navedeno je kako je planiranje, kao funkcija rukovođenja, proces povezan s odlučivanjem. Odlučivanje, nadalje, može biti programirano ili svakodnevno, odnosno rutinsko, ili neprogramirano, odnosno neredovito. Neprogramirano odlučivanje odnosi se na neočekivane i iznenadne promjene u okruženju knjižnice. Takve iznenadne i nesvakidašnje promjene mogu biti različite po svom intenzitetu, kao i po rizicima koje nose u odnosu na rad knjižnice kao ustanove. Ako je takav događaj iznenadan, intenzivan i nosi veliki rizik za sigurnost ljudi i imovinu knjižnice te ugrožava njezino poslovanje, tada je to krizni događaj.

Prema IFLA-inom kratkom priručniku za pripravnost i planiranje mjera zaštite u slučaju katastrofa u knjižnicama, upravljanje kriznim situacijama obuhvaća: (1) procjenu rizika (prepoznavanje mogućih izvora katastrofe) izvan objekta knjižnice, unutar zgrada, rizika od namjernog štetnog ljudskog djelovanja, (2) prevenciju i zaštitu koja obuhvaća okolinu zgrade, konstrukciju zgrade, njezinu sigurnost, sigurnost spremišta, osiguranje kod osiguravajućeg društva, zaštitu od vode, zaštitu od vatre, njezino otkrivanje i gašenje, (3) pripravnost za slučaj katastrofe (spremnost za katastrofu) koja obuhvaća izradu plana za slučaj katastrofe, ulogu članova tima za reakciju u konkretnom slučaju katastrofe, dostupnost plana, redovitu reviziju plana, poduku osoblja, identifikaciju prioritetne građe za spašavanje, održavanje i ažuriranje prikladne dokumentacije koja podržava implementaciju plana, uspostavu i održavanje veze s vanjskim službenicima i stručnjacima, nabavu i održavanje opreme za hitne slučajeve, (4) reakciju i odgovor na katastrofu (u tijeku katastrofe) koja obuhvaća početnu reakciju, odgovor na katastrofu, spaša-

37 Zakon o knjižnicama i knjižničnoj djelatnosti u članku 29 navodi obveze osnivača knjižnica u financiranju rada knjižnice. Usp. Zakon o knjižnicama i knjižničnoj djelatnosti. // Narodne novine 17, 356(2019). [citirano:2021-02-01]. Dostupno na: https://narodne-novine.nn.hr/clanci/ sluzbeni/2019_02_17_356.html. 
vanje te (5) obnovu nakon katastrofe koja obuhvaća usluge za korisnike, zgradu, zbirke, osiguranje te analizu katastrofe. ${ }^{38}$

Imajući u vidu citirani IFLA-in priručnik, moguće je navesti proširenu klasifikaciju područja upravljanja kriznim situacijama: (1) predviđanje mogućih izvanrednih događaja koji mogu zadesiti knjižnicu, (2) procjenu izvjesnosti nastanka pojedinih rizika, (3) procjenu osjetljivosti i ranjivosti knjižnice u odnosu na pojedine izvanredne događaje, (4) pripreme koje će se poduzeti radi sprječavanja, ublažavanja ili suočavanja s kriznim situacijama, (5) rukovođenje organizacijskim ponašanjem tijekom i neposredno nakon krize i (6) temeljito vrednovanje svih navedenih područja nakon završetka krize. ${ }^{39}$

U anticipiranju mogućih kriznih događaja koji mogu zadesiti knjižnicu, dobro je obuhvatiti sve one koje su uobičajeni, primjerice, od prirodnih događaja - kao što su poplave, vremenske nepogode, plimni valovi, zemljotresi, odroni zemlje, erupcije vulkana, epidemije, ekološke ugroze i tome slično, ili tehničko-tehnološke rizike, kao što su primjerice požari, kvarovi na instalacijama, opremi ili objektima, izlijevanje tekućina iz instalacija, ili pak društveni rizici, kao što su građanski nemiri, ratovi ili ratni sukobi, teroristički napadi itd.

Nakon što uprava i rukovodstvo knjižnice procjene osjetljivost i ranjivost knjižnice u odnosu na pojedine izvanredne događaje koji su katalogizirani kao mogući, slijede procjene mogućnosti nastanka svakog od pojedinih rizika i razine ugroženosti ustanove.

$\mathrm{Na}$ temelju takvih procjena, može se pristupiti (1) planiranju odgovarajućih preventivnih mjera i akcija, odnosno izradi planova i programa, (2) nakon toga slijedi nabava i priprema odgovarajućih materijalno-tehničkih sredstava potrebnih u pojedinim kriznim okolnostima i na kraju, (3) uvježbavanje zaposlenika za postupanje tijekom i nakon nastanka kriznog događaja.

Jedno od područja planiranja organizacijskog ponašanja u kriznim situacijama, koje se nerijetko zanemaruje, odnosi se na uklanjanje posljedica nakon što je izvanredni događaj završio. Zato je važno planirati mjere i postupke koji će se poduzeti nakon završenog kriznog događaja. Tako se nerijetko može umanjiti nastala šteta. Prema tome, upravljanje nastalom štetom važan je dio upravljanja krizom.

38 IFLA-in kratki priručnik za pripravnost i planiranje mjera zaštite u slučaju katastrofa. Zagreb: Hrvatsko knjižničarskog društvo, 2012. [citirano: 2020-10-30]. Dostupno na https://www.hkdrustvo.hr/clanovi/alib/datoteke/file/IFLA-in\%20kratki\%20prirucnik\%20za\%20pripravnost $\% 20$ $-\% 20$ McIlwaine,\%20John.pdf. Također, Disaster management for libraries and archives. / ed. M. Grahamand J. Feather. Hampshire: Ashgate, 2003.

39 Osmanagić Bedenik navodi tri područja uspješnog upravljanja krizom: (1) anticipativno upravljanje krizom, tj. preventivno djelovanje, predusretanje krize (uvođenje mjera opreza, prevencije), (2) identifikaciju krize (je li nastupila, kako ju prepoznati, koje je snage), (3) reaktivno upravljanje krizom, tj. ovladavanje krizom (što učiniti kako bi se uspješno ,izašlo“ iz krize). Usp. Osmanagić Bedenik, N. Krizni menadžment: teorija i praksa. // Zbornik Ekonomskog fakulteta u Zagrebu 8, 1(2010), str. 108-109. [citirano: 2020-10-30]. Dostupno na https://hrcak.srce.hr/file/87513. 
I na kraju, važno je nakon završetka svake krize obaviti cjelovitu evaluaciju njenog nastanka, tijeka, završetka i sanacije štete. Ona je potrebna radi izbjegavanja budućih grešaka.

Brojne aktivnosti koje se odnose na zaštitu i spašavanje ljudi i imovine već su regulirane zakonima i propisima, primjerice područje protupožarne zaštite, načini evakuacije i spašavanja ljudi i imovine, a odnedavno su izrađene i upute o postupanju tijekom pandemije bolesti COVID-19.

I na kraju pitanje: mogu li se uopće krizni događaji, koji su po svojoj prirodi nepredvidivi i neželjeni te u pravilu štetni, prevenirati i preduhitriti? Iskustvo govori da je to moguće, premda nikada potpuno. Planirajući i pripremajući se za uobičajene i očekivane krize, procjenjujući njihove moguće prijetnje i ishode, stvaraju se organizacijske i druge pretpostavke za suočavanje i s onim krizama i prijetnjama koje se nisu očekivale i pojavljivale. Primjer je toga trenutna pandemija za koju se nitko nije pripremao niti priređivao odgovarajuće planove i procedure. Međutim, knjižnice i druge njima slične ustanove relativno brzo prilagodile su svoje poslovanje novim okolnostima te nastavile s pružanjem usluga korisnicima.

\section{Zaključak}

Planiranje kao početna rukovodna funkcija ima svoje mjesto i ulogu u radu knjižnice. Za knjižnice kao poslovne organizacije može se reći da općenito imaju stabilne organizacijske strukture koje se relativno sporo mijenjanju, pri čemu se uspješno prilagođavaju promjenama koje se odigravaju u njihovim okruženjima. Njihovo poslovanje, knjižnično i neknjižnično, prenosilo se s jednog desetljeća na drugo, i može se reći da se ono u svojim bitnim odrednicama nije značajnije mijenjalo niti pojavom digitalne paradigme. Otuda je dugotrajna stabilnost osnovnih oblika organizacijskih struktura uz ustaljene, gotovo tradicionalne modele poslovanja, pridonijela njihovom postupnom usavršavanju i posljedičnom razvoju kvalitete knjižničnih i njima srodnih usluga, njihovoj diversifikaciji te, posljedično, zadovoljstvu korisnika.

Planiranje razvoja poslovanja, osobito strateško planiranje, postaje sve češćom i sve boljom praksom knjižnica, što potvrđuju i rezultati istraživanja opisanih i analiziranih u ovom radu. U uvjetima sve bržih promjena u okruženju knjižnica (primjerice, razvoj informacijsko-komunikacijskih tehnologija, eksponencijalni rast informacija i znanja itd.), strateško planiranje značajnije je nego li je to bilo krajem dvadesetog stoljeća. Strateški planovi razvoja, kao i operativni godišnji planovi hrvatskih knjižnica, postupno poprimaju oblike i sadržaje za koje je izvjesno da će se ustaliti i postati njihovom trajnijom praksom.

Razvoj informacijskih i komunikacijskih tehnologija ubrzao je prikupljanje, pohranjivanje, obradu, širenje i razmjenu informacija različitih oblika, ali nije pro- 
mijenio temeljnu svrhu knjižnica kao organizacija, odnosno kao ustanova koje pružaju knjižnične i njima srodne usluge. Knjižnice su, također, umnožile broj i vrstu svojih usluga, sustavno odgovaraju na nove želje i potrebe korisnika te su obogatile i ojačale postojeće društvene uloge, dodajući im neke nove kao što su, primjerice, prevladavanje društvene isključenosti depriviranih društvenih skupina, aktivnija uloga u razviju opće kulture, doprinos profiliranju lokalnog i nacionalnog identiteta itd.

Metodologija izrade strateških planova razvoja knjižnica i njihova razrada u operativnim (godišnjim) planovima, razvijana je prema metodama planiranja koje se koriste u gospodarskim organizacijama, ali s uspješnim i sve boljim prilagodbama i ponekim poboljšanjima, osobito onima koje se odnose na metodologiju. To je, donekle i očekivano, jer je poslovno planiranje u organizacijama. odnosno ustanovama koje u svome poslovanju ne operiraju s tržišnim i drugim rizicima (primjerice, financijskim, valutnim, kreditnim i drugim), manje zahtjevno, s obzirom na to da se knjižnice suočavaju s manjim brojem rizika kao što su primjerice rizici elementarnih nepogoda, rizici koji se odnose na društvenu, političku, ekonomsku i pravnu sigurnost itd.

I na kraju, iskustva potvrđuju da strateško i operativno planiranje rada knjižnica može značajno pridonijeti dugoročnom rastu i razvoju knjižničarstva te njegovoj organizacijskoj učinkovitosti u uspješnom obavljanju kulturnog, obrazovnog, znanstvenog, informacijskog, zabavnog i općenito, svog općeg društvenog poslanja.

\section{I T E R A T U R A}

Bačić, E. Strategija javnog zagovaranja za visokoškolske knjižnice. // Vjesnik bibliotekara Hrvatske 56, 4(2013), 53-65. [citirano: 2020-10-30]. Dostupno na https://www. hkdrustvo.hr/vjesnik-bibliotekara-hrvatske/index.php/vbh/article/view/139.

Balog, A. Prema oblikovanju organizacijske strukture knjižnice. // Vjesnik bibliotekara Hrvatske 63, 1-2(2020), 83-107. [citirano: 2021-10-30]. Dostupno na https://www. hkdrustvo.hr/vjesnik-bibliotekara-hrvatske/index.php/vbh/article/view/789/683.

Balog, A. Upravljanje knjižnicom kao poslovna funkcija. // Vjesnik bibliotekara Hrvatske 61, 2(2018), 73-97. [citirano: 2020-10-30]. Dostupno na https://www.hkdrustvo. hr/vjesnik-bibliotekara-hrvatske/index.php/vbh/article/view/666/595.

Belan-Simić, A.; I. Đukec Kero. Strateško planiranje javnozagovaračke aktivnosti knjižnica Grada Zagreba. // Vjesnik bibliotekara Hrvatske 58, 1-2(2015), 29-44. [citirano: 2020-10-30]. Dostupno na https://www.hkdrustvo.hr/vjesnik-bibliotekara-hrvatske/ index.php/vbh/article/view/52. 
Digitalne knjižnice za lokalni razvoj - DL4LD. [citirano: 2020-10-30]. Dostupno na https://croatianmakers.hr/hr/dl4ld/.

Disaster management for libraries and archives. / ed. M. Grahamand J. Feather. Hampshire: Ashgate, 2003.

Hrvatsko knjižničarsko društvo. Strategija za javno zagovaranje HKD-a 2015.-2020. [citirano: 2020-10-30]. Dostupno na https://www.hkdrustvo.hr/datoteke/1746.

Hrvatsko knjižnično vijeće. Strategija hrvatskog knjižničarstva 2018.-2022. Sjednica od 20. svibnja 2017. godine. [citirano: 2020-10-3]. Dostupno na: https://min-kulture. gov.hr/kulturne-djelatnosti-186/knjiznicna-djelatnost-361/hrvatsko-knjiznicno-vijece-522/biljeske-sa-sjednica-663/arhiva-2031/2031.

IFLA Strategy 2019 - 2024. [citirano: 2020-10-30]. Dostupno na https://www.ifla.org/ files/assets/hq/gb/strategic-plan/ifla-strategy-2019-2024-en.pdf.

IFLA-in kratki priručnik za pripravnost i planiranje mjera zaštite u slučaju katastrofa. Zagreb: Hrvatsko knjižničarsko društvo, 2012. [citirano: 2020-10-30]. Dostupno na https://www.hkdrustvo.hr/clanovi/alib/datoteke/file/IFLA-in $\% 20 \mathrm{kratki} \% 20$ prirucnik\%20za\%20pripravnost\%20-\%20McIlwaine,\%20John.pdf.

Jurić, M. Rezultati evaluacije: knjižnice. // Organizacijski razvoj i strateško planiranje u kulturi: Grad Zagreb / Sanjin Dragojević, Tihomir Žiljak. Zagreb: Pučko otvoreno učilište, 2008. Str. 190-200.

Jurina, M. Organizacija i menadžment. Zaprešić: Visoka škola za poslovanje i upravljanje s pravom javnosti Baltazar Adam Krčelić, 2011.

Kalanj, K. Strateško planiranje i razvoj projekata vezanih za specifične djelatnosti muzejske knjižnice:Knjižnica Tehničkog muzeja u Zagrebu. // Vjesnik bibliotekara Hrvatske 58, 1-2(2015), 15-28. https://www.hkdrustvo.hr/vjesnik-bibliotekara-hrvatske/index.php/vbh/article/view/51.

Katavić, I.; R. Vrana. Strateški planovi hrvatskih i inozemnih knjižnica: sličnosti i razlike. // Vjesnik bibliotekara Hrvatske 61, 1(2018), 287-320. [citirano: 2020-10-3]. Dostupno na: https://www.hkdrustvo.hr/vjesnik-bibliotekara-hrvatske/index.php/ vbh/article/view/596.

Knjižnice grada Zagreba. 65 plus. [citirano: 2020-10-30]. Dostupno na http://www.kgz. $\mathrm{hr} / \mathrm{hr} / 65$-plus-1296/1296.

Knjižnice grada Zagreba. Misija, vizija i strategija. [citirano: 2020-10-30]. Dostupno na http://www.kgz.hr/hr/o-nama/misija-vizija-i-strategija/222/.

Politika. Leksikon menadžmenta / ur. F. Bahtijarević-Šiber, P. Sikavica, P. Zagreb: Masmedia, 2001.

Majstorović, Z.; V. Čelić-Tica; J. Leščić. Strategijski plan razvoja knjižnica: s posebnim osvrtom na zadaće Nacionalne i sveučilišne knjižnice u Zagrebu. // Vjesnik bibliotekara Hrvatske 56, 1-2(2013), 35-70. [citirano: 2020-10-30]. Dostupno na https:// www.hkdrustvo.hr/vjesnik-bibliotekara-hrvatske/index.php/vbh/article/view/182. 
Mihalić, M. Mjere li sam o pokazatelji uspješnosti vrijednost knjižnica?: prema vrednovanju društvenih ciljeva organizacija u kulturi. // Vjesnik bibliotekara Hrvatske 55, 1(2012), 29-44. [citirano: 2020-10-30]. Dostupno na https://www.hkdrustvo.hr/ vjesnik-bibliotekara-hrvatske/index.php/vbh/article/view/325.

Nacrt Strategije razvoja Hrvatskog knjižničarstva 2016. - 2020. [citirano: 2020-10-3]. Dostupno na: https://esavjetovanja.gov.hr/ECon/MainScreen?entityId=1850.

Okvir smjernica za izradu pisane politike nabave građe i izgradnje zbirki u narodnim knjižnicama. [citirano: 2020-10-30]. Dostupno na http://maticna.nsk.hr/wp-content/ uploads/2019/04/smjernice-za-nabavu.pdf.

Osmanagić Bedenik, N. Krizni menadžment: teorija i praksa. // Zbornik Ekonomskog fakulteta u Zagrebu, 8, 1(2010), 101-118. [citirano: 2020-10-30]. Dostupno na https://hrcak.srce.hr/file/87513.

Osmanagić Bedenik, N. Operativno planiranje. Zagreb: Školska knjiga, 2002.

Politika zaštite knjižnične građe u Knjižnici Filozofskog fakulteta u Osijeku. [citirano: 2020-10-30]. Dostupno https://www.hkdrustvo.hr/zastita/wp-content/ uploads/2016/03/Politika-za\%c5\%a1 tite-knji\%c5\%beni\%c4\%8dne-gra\%c4\%91e-u-Knji\%c5\%benici-Filozofskog-fakulteta-u-Osijeku.pdf.

Poljak, Lj. Strateško planiranje u narodnim knjižnicama u Hrvatskoj: diplomski rad. Zadar: Odjel za informacijske znanosti Sveučilišta, 2016.

Pravilnik o financijskom izvještavanju u proračunskom računovodstvu. // Narodne novine 3, 59(2015). [citirano. 2021-02-01]. Dostupno na: https://narodne-novine. nn.hr/clanci/sluzbeni/2015_01_3_59.html.

Pravilnik o proračunskom računovodstvu i računskom planu. // Narodne novine 124, 2374(2014). [citirano. 2021-02-01]. Dostupno na: https://narodne-novine.nn.hr/ clanci/sluzbeni/2014_10_124_2374.html.

Sikavica, P.; F. Bahtijarević-Šiber; N. Pološki Vokić. Temelji menadžmenta. Zagreb: Školska knjiga, 2008.

Strategija razvoja specijalnih knjižnica u Republici Hrvatskoj: 2013. - 2015. [citirano: 2020-10-3]. Dostupno na: https://www.nsk.hr/wp-content/uploads/2012/12/Strategija-razvoja-specijanih-knjiznica_web.pdf.

Strategije razvoja sveučilišnih knjižničnih sustava u Republici Hrvatskoj: 2013. - 2015. [citirano: 2020-10-3]. https://www.nsk.hr/wp-content/uploads/2013/05/Strategija-razvoja-SKS.pdf.

Strateški plan gradske i sveučilišne knjižnice Osijek 2016. - 2020. [citirano: 2020-1030]. Dostupno na http://www.gskos.unios.hr/wp-content/uploads/2017/02/Strategija-GISKO-2016_-2020_.pdf.

Strateški plan Ministarstva kulture 2019. - 2021. [citirano: 2020-10-3]. Dostupno na: https://www.min-kulture.hr/userdocsimages/2005/Strate\%C5\%A1ki\%20plan\%20 MK\%202019.-2021.\%20-\%20Final\%20(004).pdf. 
Todorčev Hlača, K. Strategija razvoja središnjih knjižnica nacionalnih manjina unutar mreže narodnih knjižnica. // Vjesnik bibliotekara Hrvatske 58, 1-2(2015), 45-66. [citirano: 2020-10-30]. Dostupno na https://www.hkdrustvo.hr/vjesnik-bibliotekara-hrvatske/index.php/vbh/article/view/53.

Vodič kroz znanje o upravljanju projektima (Vodič kroz PMBOK). 4. izdanje. Zagreb: Mate 2011.

Weihrich, H.; H. Koontz. Menadžment. 11. izd. Zagreb: Mate, 1998.

Zakon o knjižnicama i knjižničnoj djelatnosti. // Narodne novine 17, 356(2019). [citirano:2021-02-01]. Dostupno na: https://narodne-novine.nn.hr/clanci/sluzbeni/2019_02_17_356.html. 